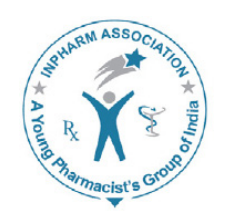

\title{
JVP
}

\section{Environmental Safety - Breath for Next Generation}

The craving from the green earth is increasing every day to serve the needs of all global leaving matters. Deforestation is one of the major problems in modern civilization, as everyone needs homes, places to constrict industries, agriculture land for cultivation, etc. Until the early $20^{\text {th }}$ century, the highest rate of deforestation occurred in Asia, Europe and North America to serve the peoples' agricultural and industrial needs. One of the major reasons for declining forest area is population increase. Four thousand year ago, China had 60 percentage of forest area with 1.4 million population 1840 the population of China reached 413 million with 17 percentage forest area. In India, 33 million hectares of forest area was cleared during the European colonization. ${ }^{1}$ Deforestation and global industrial development is increases the global emission of carbon dioxide, leading to global warming. The top six carbon-di-oxide $\left(\mathrm{CO}_{2}\right)$ emitting countries are China (29\%), USA (16\%), European Union (11\%), India (6\%), the Russian federation (5\%) and Japan (4\%). The responsibility lies on us to protect our earth from global warming and increase the percentage of forest areas. ${ }^{2}$ The emissions in developing countries like China have risen by 10\%; 40\% of the cities in China exceed their residential area quality standards. ${ }^{3}$ This example is just the tip of the iceberg. If this is allowed to continue without any corrective action being taken, the same deleterious effects will be seen in all the major cities of the world.

In the US, each year about 200,000 people are dying because of environmental air pollution. The WHO estimated that in 2012 around 7 million people died worldwide due to air pollution. ${ }^{4,5}$ Around 5.9 million died due to air pollution in low- and middle-income countries in the WHO South-East Asia and Western Pacific Regions in 2012. Air pollution increases the risk of cardiovascular, respiratory and central nervous systemic diseases or disorders (7 million premature deaths annually linked to air pollution). The Bhopal (India) gas tragedy that occurred on the night of
2 -3 December 1984 at Union Carbide India Ltd., was one of the worst industrial disasters, killing 3,787 and caused $>$ 100,000 permanent injuries. ${ }^{6}$ The major sources for environmental pollutions are chemicals, petrochemicals and pharmaceutical industries. These industries are sensitizing/ using/ formulating to produce desired products based on public needs. The needs are increasing daily to fulfill the civilian's requirements. But, the key issue is how to destroy/ discard/destruct the industrial waste or bio-waste materials. The cost for disposal is higher than manufacturing and most of the people in Asian countries just dump the waste materials in the earth, which is not good when considering the future. This will affect a host of domains, primarily agriculture.

This earth is ours. It is the responsibility of every individual to reduce/control pollution and point the same to the future generations. The increase in forest area may show major changes in our ecological system and also help us to live in a healthy manner. The cosmopolitan/ultra-modern life though having many benefits, has also resulted in many diseases which shorten the lifespan of each individual. To restore the nature consuming lot of money and, man power than forestation and also most of the attempt are getting fail. Hence, each one of us must take a lead to save our environment by

- seeding at least one tree in our life time.

- appropriate disposal of industrial and biological wastes.

- keeping our immediate surroundings clean.

- avoiding wasting of natural resources.

Small initiations of this sort from each and every one of us may produce grater changes in our earth; and in doing so, we gift a healthy, clean and green environment for our future generation. 


\section{REFERENCES}

1. State of the World's Forests 2012. Food and agriculture organization of the united nations, Rome, 2012. Available in http://www.fao.org/docrep/016/i3010e/i3010e. pdf [last accessed on 19/12/2014].

2. Trends inglobal CO2 emissions 2013 report. PBL Netherlands Environmental Assessment Agency. The Hague, 2013 Available in http://edgar.jrc.ec.europa. eu/news_docs/pbl-2013-trends-in-global-co2-emissions-2013-report-1148.pdf [last accessed on 19/12/2014].

3. Jakuboski S. The impact of Asian air pollution on the World's weather, January 2014. Available in http://www.nature.com/scitable/blog/green-science/the_impact_ of_asian_air [last accessed on 19/12/2014].

4. Air Pollution Causes 200,000 Early Deaths in US. Available in http://www.voanews. com/content/air-pollution-linked-to-early-death/1739804.html [Last accessed on 20/12/2014].

5. 7 million premature deaths annually linked to air pollution. Available in http:// www.who.int/mediacentre/news/releases/2014/air-pollution/en/ [Last accessed on 20-12-2014].
6. Syamittra B, Parasuraman S, Yeng WY, Ping WY, Sujithra J, Kumar J, et al. A Review on Adverse Health Effects of Laboratory Volatile Solvents, International Journal of Clinical Therapeutics and Diagnosis. 2014: 2: 702.

Thank you for reading

With Regards

Dr. S. Parasuraman, Editor-in-Chief, Journal of Young Pharmacist. Email: jypeditor@gmail.com

DOI : 10.5530/jyp.2015.2.1 